The Journal of Animal \& Plant Sciences, 30(3): 2020, Page: 576-585

ISSN (print): 1018-7081; ISSN (online): 2309-8694

\title{
EFFECTS OF SILAGE EFFLUENT, UREA-MOLASSES AND WATER TREATMENT ON IN SITU RUMEN DEGRADATION AND MICROBIOLOGICAL TRAITS OF WHEAT STRAW
}

\author{
H. G. Qutab-ud-din and M. Macit \\ Department of Animal Science, Agricultural Faculty, Ataturk University, 25240, Erzurum, Turkey \\ *Corresponding author's email: mmacit@atauni.edu.tr
}

\begin{abstract}
This experiment was carried out to determine the effects of silage effluent, urea-molasses and water treatment on in situ disappearance of dry matter (DM), organic matter (OM), crude protein (CP), acid detergent fiber (ADF), and neutral detergent fiber (NDF) of wheat straw, and its degradation parameters $(a+b+c$ and $a+b)$ and effective degradability (ED). There were six treatments: including control (W), $\mathrm{W}+$ silage effluent $(\mathrm{WS}), \mathrm{W}+$ silage effluent + water + urea + molasses (WSHUM), $\mathrm{W}+$ urea + molasses + water (WUMH), $\mathrm{W}+$ urea + molasses (WUM) and W+ water (WH). Except control and WH groups, all other groups were set iso-caloric and iso-nitrogenous and calculated amount of urea and molasses equal to nitrogen and energy value from silage effluent were added to treatment groups. All treatment groups were packed in sealed plastic bucket made by polypropylene, and they were subjected to 45 days of anaerobic fermentation. Four rumen cannulated Holstein bulls of $400 \mathrm{~kg}$ and 20 months of age were utilized. The extent and rate of $\mathrm{DM}, \mathrm{OM}, \mathrm{CP}, \mathrm{ADF}$ and NDF disappearance was determined by using randomized block design where animals were blocking factor. After fermentation, all treatments were incubated to rumen for 4, 8, 16, 24, 48, 72 and $96 \mathrm{~h}$ using nylon bag technique. Data of in situ DM, OM, CP, ADF and NDF degradability were subjected to one-way ANOVA using the GLM procedure. A completely randomized design was used in which treatment groups were the fixed factor. Differences in terms of DM, OM, CP, ADF and NDF degradabilities among the treatments were significant $(p \leq 0.05)$. Treatment with silage effluent increased rumen degradability of wheat straw $(p \leq 0.05)$. Also, treating wheat straw with silage effluent hindered the growth of pathogenic microorganisms. In conclusion, treating low quality roughages i.e. wheat straw with silage effluent which is rich in nutrient could be recommended not only to improve fermentation quality of wheat straw but also to increase its degradation in rumen. Further, addition of silage effluent can preserve the ensilage from undesired pathogen i.e. yeast, coliform, clostridia and fungal growth.
\end{abstract}

Keywords: in situ degradability; ADF; NDF; Silage effluent; Wheat straw. https://doi.org/10.36899/JAPS.2020.3.0068 Published online March 25, 2020

\section{INTRODUCTION}

Wheat straw, a major agricultural residue, is abundantly produced throughout the world. On an average one $\mathrm{kg}$ wheat grains produce $1.2-1.3 \mathrm{~kg}$ of straw (Dai et al., 2016). In Turkey, approximately 29.8 million tons wheat straw is being produced annually (Ak and Akbay, 2018). Most of this by-product is fed to animals. It contains lignocellulosic material including $35-37 \%$ cellulose, $25 \%$ hemicellulose, $10-15 \%$ lignin, and $5-10 \%$ mineral and other components (Merali et al., 2013; Liu et al., 2014). These cell wall structures are less available for microbial degradation in rumen. Hence, less energy and low protein contents make it less favorable to use as feed stuff (Yang et al., 2006; Chaturvedi and Verma, 2013).

Previously, treatment of wheat straw with chemicals (Chandra et al., 2012; Chaturvedi and Verma, 2013; Li et al., 2013), fungal enzymes (Van Kuijk et al., 2015), and lactobacillus bacteria (Ni et al., 2014) has been employed to improve digestibility. Silage effluent, an agricultural pollutant, is abundantly generated worldwide. This environmental pollutant liquid is rich in lactobacillus bacteria with acidic $\mathrm{pH}(3.24-4.5)$ and 6$10 \%$ dry matter. Effluent's contains $19-33 \%$ CP, $40-42 \%$ water soluble carbohydrates (WSC) and $15-25 \%$ ash on a dry matter (DM) basis (Patterson et al., 1979; Gebrehanna et al., 2014; Yildiz et al., 2016). The amount of effluent produced varies between 5 and $20 \%$ depending on DM of ensiled crop (Gebrehanna et al., 2014), extent of chopping and pressing (Johnson et al., 2002; Holmes and Muck, 2007), use and type of additives (Yitbarek and Tamir, 2014), and pressure applied on surface (Alli et al., 1985). Disposal of effluent is major constraint in livestock production. In previously studies, silage effluent has been fed to pigs and dairy cattle (Patterson et al., 1979; Randby, 1997), and used for soil treatment (Yildiz et al., 2016). However, no standard method has been developed for its disposal or effective use. Lactobacillus (LAB) inoculant along with WSC source has been successfully used to improve fermentation quality of wheat straw (Ni et al., 2014), but its effect on digestion has not been studied. The aim of 
this experiment was to determine the nutrient composition of silage effluent and its effect on in situ degradation of wheat straw by using in situ nylon bag technique. Furthermore, the comparative degradation parameters of other treatments were also studied.

\section{MATERIALS AND METHODS}

Treatments: Wheat straw (Triticum aestivum cv. Barbela) was obtained from Research and Application Farm of Agriculture Faculty, Ataturk University, Erzurum. Silage effluent was provided from corn crop after fermentation ensiled at this Research Farm in October 2016 (Yildiz et al., 2016). Before mixing, chemical and microbial analysis of wheat straw and effluent were performed (Table 1). Six treatment groups were established: 1. control (W), 2. straw + ureamolasses (WUM), 3. straw + water (WH), 4. straw + water + urea-molasses (WHUM), 5. straw + silage effluent (WS), and 6 . straw $+50 \%$ silage effluent $+50 \%$ water + urea-molasses (WSHUM) (Table 2). Required amount of effluent and water was added, and dry matter content in WH, WHUM, WS and WSHUM was kept $40 \%$. Except for control and WH groups, all other groups were set iso-caloric and iso-nitrogenous and calculated amount of urea and molasses equal to nitrogen and energy value from silage effluent (Table 1) was added to treatment groups. All treatment groups were packed in sealed plastic bucket made by polypropylene and allowed fermentation for 45 days. After fermentation, the fermented straws were dried and ground to $2-2.5 \mathrm{~mm}$ before rumen incubation.

\section{Physical and Microbial Analysis: After}

45-day

fermentation, the quality of ensiled treatment groups with respect to color, odor and purification (moldiness) was analyzed (Kılıç, 1986; Filya, 2000). Microbial analysis including total bacterial count, lactobacillus (LAB) and coliform bacteria, yeast and mold of treatment groups and silage effluent was performed (Seale et al., 1990).

Chemical Analysis: Dry matter, crude protein (CP), ether extract, WSC of silage effluent, 45-day fermented treatment groups and rumen incubated residues were measured (AOAC, 1990). Fiber analysis (Van Soest et al., 1991) was done using Ankom Fiber Analyser 2000 (ANKOM Technology, Macedon, NY). Heat stable amylase was used to determine neutral detergent fiber (aNDFom). Acid detergent fiber (ADFom) and other fiber fractions are expressed excluding residual ash.

Animals and Diets: To determine in situ degradation of treated wheat straw, four rumen cannulated Holstein bulls of $400 \mathrm{~kg}$ and 20 months of age were housed individually on concrete floor and fed according to $1.25 \mathrm{x}$ maintenance
(NRC 2001) ration containing 55\% concentrate, 20.5\% dried grass, $20.5 \%$ alfalfa hay and $4 \%$ wheat straw.

The ethical approval for this experiment was taken from Local Ethics Committee of Animal Experiment, Ataturk University, Erzurum, Turkey.

In situ Rumen Incubation: The extent and rate of DM, $\mathrm{OM}, \mathrm{CP}, \mathrm{ADF}$ and NDF disappearance was determined by using randomized block design where animals were blocking factor. Five $\mathrm{g}$ sample from each treatment, in duplicate, was taken in nylon bags measuring $10 \times 15 \mathrm{~cm}$ (length and width) with the pore size of 50-60 $\mu \mathrm{m}$. The bags closed and tied with nylon finishing line were incubated in the rumen for $4,8,16,24,48,72$ and 96 hours and removed at same time. After removal the bags were soaked in cold water and then washed with running tab water till rinse was clear. To determine $0 \mathrm{~h}$ disappearance (washing loss) duplicate bags from each sample were taken into bag but without hanging in rumen washed with running tab water as described above (Jalilvand et al., 2008). After room aeration bags were dried at $55^{\circ} \mathrm{C}$ for 48 hours and weighed, and residues were ground to $1 \mathrm{~mm}$ and saved for later analysis.

Calculations: The disappearance of DM, OM, CP, ADF and NDF for each incubation time were calculated from the proportion remaining post rumen incubation. This rumen disappearance rate was fitted into following exponential model of Ørskov and McDonald (1979), and $\mathrm{a}, \mathrm{b}$ and $\mathrm{c}$ values of each treatment group were estimated using NEWAY program (McDonald, 1981). Apparent degradability was denoted by $\mathrm{a}+\mathrm{b}$ (upper asymptote).

$$
\mathrm{P}=\mathrm{a}+\mathrm{b}\left(1-\mathrm{e}^{-\mathrm{ct}}\right)
$$

where ' $\mathrm{P}$ ' is the disappearance at time ' $\mathrm{t}$ ', ' $\mathrm{a}$ ' represents washing loss (or quickly degradable fraction), 'b' denotes slowly degradable fraction and ' $c$ ' is constant rate of degradation of ' $b$ ' (Palangi and Macit, 2019). Effective degradability (ED) was calculated using following equation (Ørskov and McDonald, 1979).

$$
\mathrm{ED}=\mathrm{a}+[\mathrm{bc} /(\mathrm{c}+\mathrm{k})] \quad \text { (2) }
$$

where ' $a$ ' ' $b$ ' and ' $c$ ' are the constants as described earlier in the non-linear equation above and ' $\mathrm{k}$ ' the rumen fractional outflow rate $(0.02 / \mathrm{h}, 0.05 / \mathrm{h}, 0.08 / \mathrm{h})$.

Statistical Analysis: Data were analyzed under completely randomized design using a General Linear Model (GLM) procedure of SAS (SAS Institute Inc. 2004), Duncan (1955)'s multiple range test was used for the comparison of means. Feeds were the only sources of variation considered. Following mathematical model was assumed for statistical analysis.

$$
Y_{i j}=\mu+T_{i}+e_{i j}
$$

where; $Y_{i j}$ represents dependent variable; $\mu$ is general mean; $T_{i}$ is effect of treatment ( $\left.i=6\right)$; $e_{i j}$ is random error associated with $\mathrm{j}^{\text {th }}$. observation on $\mathrm{i}^{\text {th }}$ treatment. 


\section{RESULTS AND DISCUSSION}

Ensiling wheat straw after 5 different treatments showed difference in color and smell (Table 3). Based on color, smell and moldiness; straw containing silage effluent was of good quality with typical fruity smell and brownish yellow (olive drab) color. WH and WHUM were moldy and WH group was worst with putrefying smell and blackish brown color.

After 45-day fermentation, both WS and WSHUM silages were of good quality containging $10^{8}$ (cfu g-1 LAB) (Table 3). This result fulfils the criteria reported by (Zielinska et al., 2015) that during fermentation silages are preserved when LAB reaches at least $10^{5}$ (cfu g-1). Improvement in fermentation quality of WS and WSHUM groups can be explained according to the Yitbarek and Tamir (2014) where explained that addition of sugar and LAB inoculant increased fermentation. Inoculation of lactobacillus bacteria of effluent lowered $\mathrm{pH}$ by converting the WSC into organic acids and restricted the growth of mold, coliform and other pathogenic bacteria (Ni et al., 2014; Zielinska et al., 2015). Straw fermented with urea-molasses and $60 \%$ moisture content (WHUM) had better quality and more LAB than that which had no moisture but urea-molasses (WUM). These results agreed to the findings ( $\mathrm{Ni}$ et al., 2014) which proved the importance of moisture during fermentation. Straw ensiled with water (WH) was putrefied, and had layer of mold and high pathogenic bacteria (Table 3). The poor fermentation of straw without sugar additive (WH) has also been reported by Yitbarek and Tamir (2014) where sugar proved as a limiting factor in good quality fermentation.

Chemical composition of all treatment groups after 45-day fermentation had variable CP, ash, CF, ADF and NDF contents, but there was no significant variation in DM content of all treatments (Table 4). An increase in $\mathrm{CP}$ contents was noted in all treatments compered to control group. WSHUM and WUM had the highest CP while it was similar for WHUM and WS groups.

No research work on chemical composition of effluent treated wheat straw has so for been conducted elsewhere, so the published data on this aspect is not available for comparison. However, it can be explained in a way that, presence of WSC and lactobacillus may have increased fermentation by decreasing $\mathrm{pH}$ in effluent treated silages. Most probably this decrease in $\mathrm{pH}$ helped NH3 to make bond with fibrous material by changing it into free ionic form as previously described (Oladosu et al., 2016). Similarly, trapping of free ammonia by organic acids has also been reported earlier (Borhami et al., 1982; Elobied et al., 2013). The higher CP content of silage treated with water than control reinforce the views of (Seale et al., 1986) that presence of E.coli and clostridia bacteria in putrefied silages may cause higher $\mathrm{N}$ concentration. Ash contents of both silage effluent containing (WS, WSHUM) groups increased compared to control group but for other groups no big variation was noted. There was a decrease in crude fibers, ADF and NDF contents of silage effluent treated groups while it was higher for WH, WUM, WHUM groups than control. The reduction in NDF and ADF contents of WS and WSHUM during fermentation was due to hydrolysis of fiberous material caused by microbes as previously documented (Ni et al., 2014; Oladosu et al., 2016). Mahrun-Nisa et al. (2004) confirmed that straw treatment with urea and corn steep liquor increased NDF and ADF contents by increasing neutral detergent insoluble nitrogen (NDIN) concentration. They explained that most of $\mathrm{N}$ produced during fermentation of urea-carbohydrate (WSC) treated straw, held in form of NDIN which results in NDF and ADF increased concentration. In present study, urea-molasses treatment (WUM, WHUM) increased NDF and ADF contents of ensiled wheat straw. The entire increase in NDF and ADF in WUM and WHUM was due to fiber-N bond. These results are in convenience with the findings of other researchers (Brown et al., 1987).

The pattern of DM, OM, CP, ADF and NDF disappearance during $0,4,8,16,24,48,72$ and 96 hours rumen incubation has been illustrated in Fig 1-5. The disappearance of DM, OM, CP, ADF and NDF for almost all incubation periods was higher in the WUM, WHUM, WS and WSHUM groups than the control group ( $\mathrm{p} \leq$ $0.05)$. Despite same nutrient loss from nylon bag at $0 \mathrm{~h}$, the DM, OM, CP, NDF and ADF disappearance of WHUM was lower than WS. The disappearance of DM, $\mathrm{OM}, \mathrm{CP}, \mathrm{ADF}$, and NDF for almost all incubation periods was higher for silage effluent treatments $(\mathrm{p} \leq$ $0.05)$. The loss of OM, ADF and NDF at $96 \mathrm{~h}$ for $\mathrm{WH}$ was lower than control $(\mathrm{p} \leq 0.05)$, while $\mathrm{DM}$ and $\mathrm{CP}$ disappearance for same groups was not different from control group $(p>0.05)$. The disappearance of DM of urea-molasses treated wheat straw increased significantly $(\mathrm{p} \leq 0.05)$. These results were in agreement to the findings of some other workers (Gupta et al., 1977; Dass et al., 2000). The disappearance of CP and ADF was high for WS group while NDF disappearance was high for WSHUM group. Similarly, increase in rumen disappearance of $\mathrm{CP}, \mathrm{NDF}, \mathrm{ADF}$ due to urea treatment has also been reported by (Dass et al., 2000). No significant difference was found in $\mathrm{DM}$ and $\mathrm{OM}$ disappearance of WS and WSHUM ( $p>0.05)$. WHUM had more nutrient loss than WUM group $(p \leq 0.05)$. The difference between WUM and WHUM degradation could be attributed to higher fermentation in later group due to presence of moisture and energy. These results from present study were within the observations of most of the earlier studies (Gupta et al., 1977; Ni et al., 2014). The sugar is a limiting factor during fermentation and lactobacillus use sugar for fermenting ensilage material (Gupta et al., 1977; Seale et al., 1990). Therefore, wheat 
straw ensiled with water without adding sugar (WH) fermented poorly. Presence of coliform and other pathogen bacteria (clostridia) in silages are generally considered detrimental (Zhang et al., 2017). In present study, negative effect of water treatment (WH) on rumen degradation could be due to presence of anaerobic pathogens which had restrict rumen microflora from digestion.

The ensiling of wheat straw with silage effluent increased the ruminal disappearance of DM, CP, NDF and ADF almost for every incubation time. Both WS and WSHUM had higher nutrient loss in rumen at $96 \mathrm{~h}$ than other treatment (Fig. 1-5). This increase in rumen degradation may be due to physio-chemical changes occurred in the cell wall during microbial fermentation as described by Zorrilla-Rios et al., (1985) and Mahr-unNisa et al.-(2004). They reported that NH3 produced during fermentation increases the fragility of wheat straw. Increase in fragility of cell wall due to microbes has also been documented ( $\mathrm{Ni}$ et al., 2014). In present study, linkage between lignin-cellulose or lignin-hemicellulose may have been hydrolyzed by enzymes, released during microbial fermentation. However, degradation pattern of silage effluent treated straw can not be compared with previous literature as almost no published data related to this aspect is available.

The estimates of $a, b, c$ and $a+b$ for control and treated groups of wheat straw are given in table 5 . There was large variation in "a" fractions among all groups ( $\mathrm{p} \leq$ $0.05)$. Rapidly degradable "a" fraction of all nutrients was highest for both silage effluent treatments $(p \leq 0.05)$. Water treatment had lowest "a" fraction for DM, OM and NDF $(p \leq 0.05)$. However, "a" fraction in control group for $\mathrm{CP}$ and ADF was lowest $(\mathrm{p} \leq 0.05)$. Straw ensiled with urea-molasses had less "a" fraction of all nutrients than that treated with urea-molasses and water $(p \leq 0.05)$.

The slowly degradable fractions " $\mathrm{b}$ " of DM, $\mathrm{OM}, \mathrm{CP}, \mathrm{ADF}$ and NDF were greatest for both silage effluent (WS, WSHUM) treatments $(\mathrm{p} \leq 0.05)$. The difference of "b" fraction between control and water treated straw (WH) was significant for DM, CP and NDF $(\mathrm{p} \leq 0.05)$ and non-significant for $\mathrm{OM}$ and $\operatorname{ADF}(\mathrm{p}>$
0.05). There was large variation between WUM and WHUM treatment groups in terms of "b" fractions. This fraction of WHUM was high for DM and NDF and low for CP than WUM $(p \leq 0.05)$ while this " $b$ " fraction of $\mathrm{OM}$ and ADF was similar between these two groups ( $p>$ $0.05)$.

There was significantly variation in degradation rate of all treatment groups. Control group had faster degradation rate of OM and ADF while WUM group had highest "c" fraction of DM and CP $(p \leq 0.05)$ (Table 5). Differences in degradation rate of NDF among the WUM, WH and WHUM were insignificant $(\mathrm{p}>0.05)$, and but these feed groups had higher NDF values than those of other treatment groups ( $\mathrm{p} \leq 0.05)$.

Effective degradability (ED) values decreased consistently with the increase in rumen outflow rates (Table 5). At all three rumen outflow rates $(0.02 / \mathrm{h}$, $0.05 / \mathrm{h}, 0.08 / \mathrm{h}$ ), ED values of $\mathrm{OM}$ and $\mathrm{CP}$ were highest in WSHUM, for ADF it was high in WS group $(\mathrm{p} \leq 0.05)$ while for DM and NDF, this ED value was significantly same $(p>0.05)$ in both WS and WSHUM (Table 5). ED of $\mathrm{OM}$ and $\mathrm{ADF}$ was lowest $(\mathrm{p} \leq 0.05)$ for water treated straw while difference among ED values of DM, CP and NDF for control and WH groups was not significant $(p>$ $0.05)$.

Though some studies related to the effects of silage effluent, urea-molasses and water treatment on in situ disappearance of dry matter (DM), organic matter $(\mathrm{OM})$, crude protein $(\mathrm{CP})$, acid detergent fiber (ADF), and neutral detergent fiber (NDF) of wheat straw, there have been no reports about the effects of mentioned treatments on the degradation parameters $(a+b+c$ and $\mathrm{a}+\mathrm{b}$ ) and effective degradability (ED) of wheat straw. Hence, current study was carried out to determine the effects of silage effluent, urea-molasses and water treatment on the degradation parameters $(\mathrm{a}+\mathrm{b}+\mathrm{c}$ and $\mathrm{a}+\mathrm{b})$ and effective degradability (ED) of wheat straw. However, degradation parameters and effective degradability of silage effluent treated straw may not be compared with previous literature because there have been no published article related to this aspect is available. 

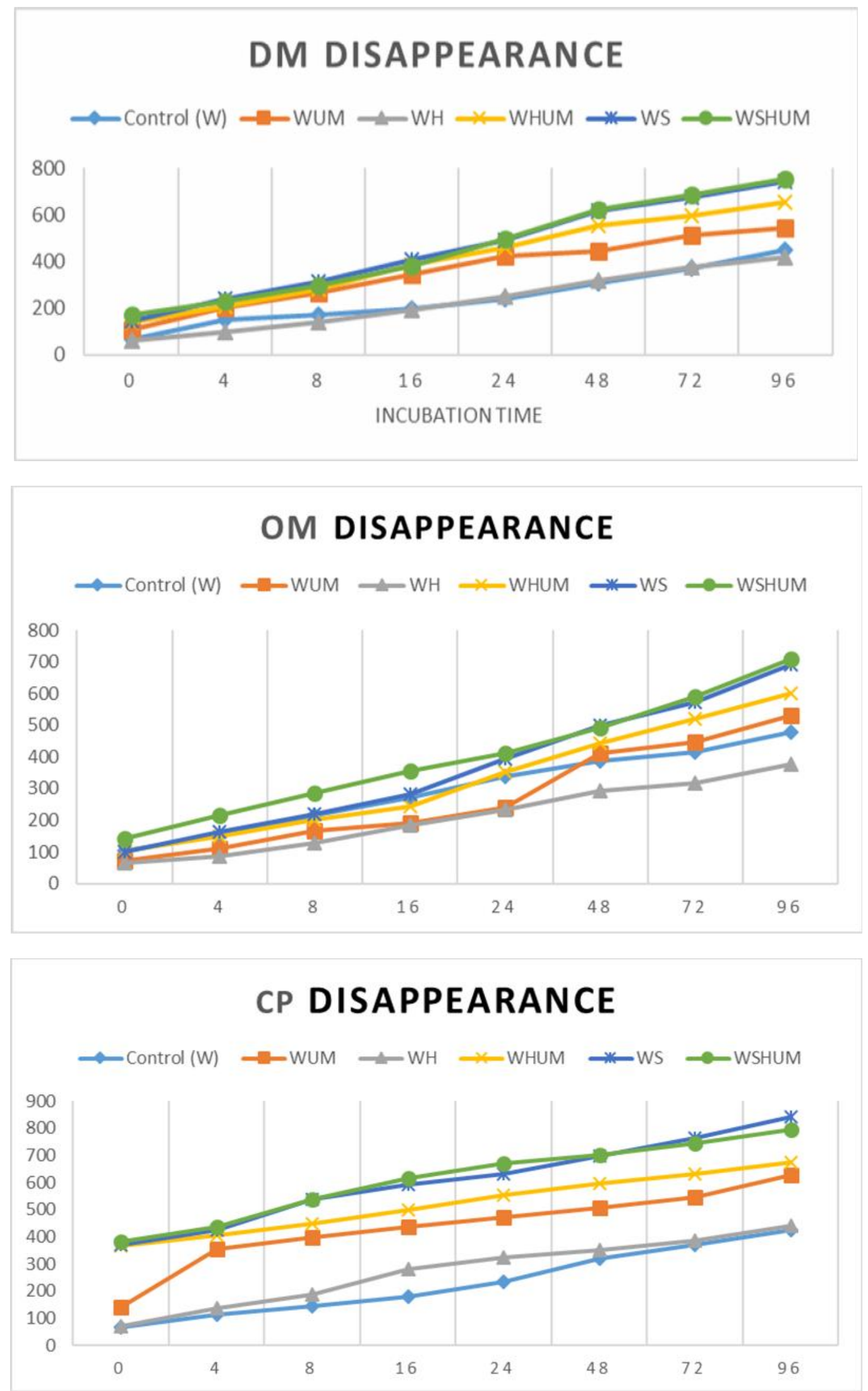

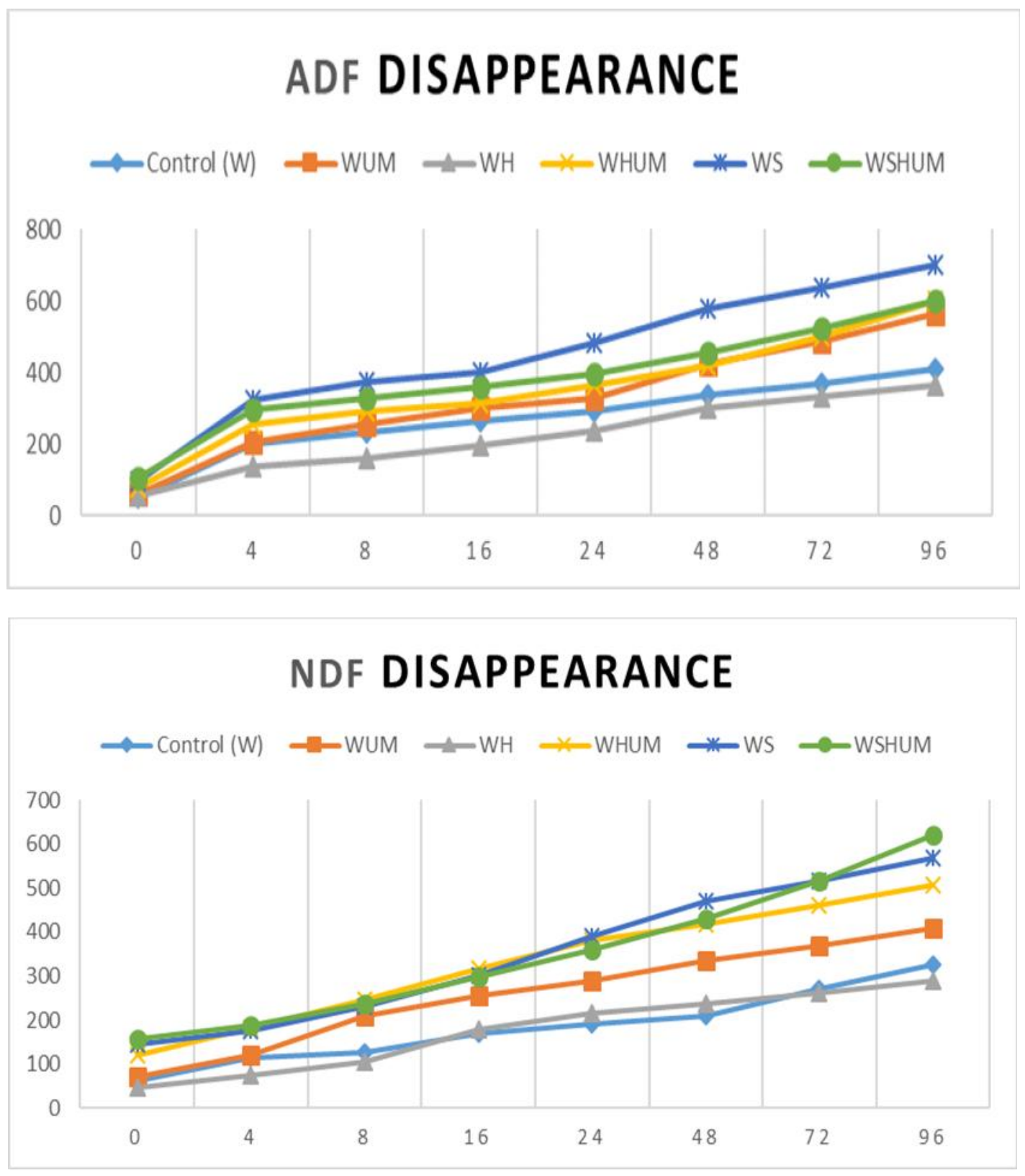

Table 1. Chemical compositions of wheat straw and silage effluent.

\begin{tabular}{|c|c|c|c|}
\hline Wheat Straw (W) & & Silage Effluent (S) & \\
\hline Dry Matter $(\mathrm{DM})(\mathrm{g} / \mathrm{kg})$ & 924 & Dry Matter $(\mathrm{DM})(\mathrm{g} / \mathrm{kg})$ & 120 \\
\hline $\begin{array}{l}\text { Nutrient composition } \\
(\mathrm{g} / \mathrm{kg} \mathrm{DM})\end{array}$ & & $\begin{array}{l}\text { Nutrient composition } \\
\text { (g/kg DM) }\end{array}$ & \\
\hline Crude Protein (CP) & 43 & Crude Protein $(\mathrm{CP})$ & 177 \\
\hline Crude Fat (EE) & 20 & Crude Fat (EE) & 8 \\
\hline Crude Ash (CA) & 71.5 & Crude Ash (CA) & 290 \\
\hline Crude Fiber (CF) & 320 & $\mathrm{pH}$ & 4.06 \\
\hline NDF & 675 & Water Soluble Carbohydrate (WSC) & 420 \\
\hline $\mathrm{ADF}$ & 428 & & \\
\hline
\end{tabular}


Table 2. Various treatments of wheat straw and other ingredients for ensiling.

\begin{tabular}{ccc}
\hline Treatment Groups & Straw (g) & Additives (g) \\
\hline Control (W) & 600 & -- \\
W + Urea + Molasses (WUM) & 600 & Urea: 8.326 \\
$\mathbf{W}+$ Water (WH) & 600 & Molasses: 75.6 \\
& & Water: 787.50 \\
W + Water + Urea+ Molasses (WHUM)) & 657.50 \\
W + Silage effluent (WS) & 600 & Urea: 8.326 \\
& & Molasses: 75.6 \\
$\begin{array}{c}\text { W+50\% Silage effluent + 50\% water + Urea + } \\
\text { Molasses (WSHUM) }\end{array}$ & 600 & Silage effluent: 1125 \\
& & Silage effluent 577.50 \\
Water 408.7 \\
Molasses: 37 \\
Urea: 4.12
\end{tabular}

Table 3. Physical (color, smell and moldiness) characters and microbial composition of silages under various treatment after 45 days of fermentation.

\begin{tabular}{|c|c|c|c|c|c|c|c|}
\hline $\begin{array}{c}\text { Treatment } \\
\text { Groups }\end{array}$ & Color & Smell & Observation & Total & $\mathrm{LAB}^{2}$ & $\begin{array}{l}\text { Coliform } \\
\text { bacteria }\end{array}$ & $\begin{array}{l}\text { Mold } \\
\text { Yeast }\end{array}$ \\
\hline WUM & Yellow & Slight vinegar & & $4.1 * 10^{8}$ & $4.1 * 10^{4}$ & ND & $1.1 * 10^{5}$ \\
\hline WH & $\begin{array}{c}\text { Blackish } \\
\text { brown }\end{array}$ & Putrefying & $\begin{array}{l}8-10 \mathrm{~cm} \\
\text { moldiness }\end{array}$ & $2 * 10^{10}$ & $4.1 * 10^{6}$ & ${ }^{*}>10^{8}$ & $4.6^{*} 10^{7}$ \\
\hline WHUM & $\begin{array}{c}\text { Light } \\
\text { yellow }\end{array}$ & Vinegar & $\begin{array}{l}2-3 \mathrm{~cm} \\
\text { moldiness }\end{array}$ & $8.4 * 10^{8}$ & $6.8 * 10^{9}$ & ND & $7.6^{*} 10^{7}$ \\
\hline WS & $\begin{array}{l}\text { Brownish } \\
\text { yellow }\end{array}$ & Typical fruity & & $5.9 * 10^{8}$ & $2.5 * 10^{8}$ & ND & ND \\
\hline WSHUM & $\begin{array}{l}\text { Brownish } \\
\text { Yellow }\end{array}$ & Typical fruity & & $5.9 * 10^{9}$ & $6.3 * 10^{8}$ & ND & ND \\
\hline
\end{tabular}

Table 4. Chemical composition of various treatment groups after 45 days of fermentation.

\begin{tabular}{lccccccc}
\hline $\begin{array}{l}\text { Item } \\
\text { Chemical Composition }\end{array}$ & Control (W) & WUM & WH & $\begin{array}{c}\text { Treatment }^{\mathbf{1}} \\
\text { WHUM }\end{array}$ & WS & WSHUM & SEM \\
DM & 940.56 & 941.87 & 946.07 & 938.58 & 933.3 & 940.04 & 1.78 \\
Ash & 100.36 & 99.79 & 102.45 & 102.92 & 141.08 & 120.95 & 6.97 \\
CP & 48.66 & 85.12 & 55.08 & 79 & 76.32 & 98.8 & 3 \\
CF & 323.75 & 325.15 & 372.15 & 355.6 & 285.05 & 305.5 & 3.9 \\
NDF & 675.35 & 682.3 & 722.85 & 704.4 & 570.75 & 619.15 & 5.1 \\
ADF & 427.55 & 437.05 & 484 & 450.8 & 366.15 & 398.4 & 6.03 \\
$\dagger$ In treatments: WUM=Wheat straw-urea-molasses, WH= Wheat straw-water, \\
WHUM= Wheat straw-water- urea+ molasses, WS= Wheat straw-silage effluent \\
WSHUM = Wheat straw-50\% silage effluent-50\% water-urea- molasses \\
SEM= Standard error of mean
\end{tabular}


Table 5. In situ rumen digestion kinetics and effective degradability of nutrients $(\mathrm{g} / \mathrm{kg})$ in control and treated feed groups.

\begin{tabular}{|c|c|c|c|c|c|c|c|c|}
\hline \multirow[t]{2}{*}{ Item $^{1}$} & \multicolumn{7}{|c|}{ Treatments } & \multirow[b]{2}{*}{ P values } \\
\hline & Control (W) & WUM & WH & WHUM & WS & WSHUM & SEM $^{2}$ & \\
\hline \multicolumn{9}{|c|}{ Dry matter (DM) } \\
\hline$A$ & $0.104^{\mathrm{d}}$ & $0.119^{\mathrm{c}}$ & $0.066^{\mathrm{e}}$ & $0.142^{\mathrm{b}}$ & $0.162^{\mathrm{a}}$ & $0.167^{\mathrm{a}}$ & 0.003 & $\leq 0.001$ \\
\hline$B$ & $0.439^{c}$ & $0.403^{\mathrm{cd}}$ & $0.377^{\mathrm{d}}$ & $0.504^{\mathrm{b}}$ & $0.581^{\mathrm{a}}$ & $0.611^{\mathrm{a}}$ & 0.017 & $\leq 0.001$ \\
\hline$C$ & $0.015^{\mathrm{e}}$ & $0.054^{\mathrm{a}}$ & $0.027^{\mathrm{d}}$ & $0.04^{\mathrm{b}}$ & $0.034^{\mathrm{c}}$ & $0.029^{\mathrm{cd}}$ & 0.002 & $\leq 0.001$ \\
\hline$a+b$ & $0.543^{\mathrm{c}}$ & $0.521^{\mathrm{c}}$ & $0.443^{\mathrm{d}}$ & $0.646^{\mathrm{b}}$ & $0.743^{\mathrm{a}}$ & $0.778^{\mathrm{a}}$ & 0.018 & $\leq 0.001$ \\
\hline $\mathrm{ED}^{2}$ & $0.289^{\mathrm{d}}$ & $0.41^{\mathrm{c}}$ & $0.277^{\mathrm{d}}$ & $0.476^{\mathrm{b}}$ & $0.529^{\mathrm{a}}$ & $0.53^{\mathrm{a}}$ & 0.008 & $\leq 0.001$ \\
\hline $\mathrm{ED}^{5}$ & $0.203^{\mathrm{d}}$ & $0.326^{\mathrm{c}}$ & $0.194^{\mathrm{d}}$ & $0.365^{b}$ & $0.398^{\mathrm{a}}$ & $0.393^{\mathrm{a}}$ & 0.006 & $\leq 0.001$ \\
\hline $\mathrm{ED}^{8}$ & $0.172^{\mathrm{d}}$ & $0.279^{\mathrm{c}}$ & $0.158^{\mathrm{e}}$ & $0.309^{b}$ & $0.336^{\mathrm{a}}$ & $0.331^{\mathrm{a}}$ & 0.005 & $\leq 0.001$ \\
\hline \multicolumn{9}{|c|}{ Organic matter (OM) } \\
\hline$A$ & $0.109^{b}$ & $0.077^{\mathrm{c}}$ & $0.064^{\mathrm{d}}$ & $0.108^{\mathrm{b}}$ & $0.113^{\mathrm{b}}$ & $0.177^{\mathrm{a}}$ & 0.004 & $\leq 0.001$ \\
\hline$B$ & $0.36^{\mathrm{c}}$ & $0.596^{\mathrm{ab}}$ & $0.357^{\mathrm{c}}$ & $0.567^{\mathrm{b}}$ & $0.647^{\mathrm{a}}$ & $0.608^{\mathrm{ab}}$ & 0.025 & $\leq 0.001$ \\
\hline$C$ & $0.04^{\mathrm{a}}$ & $0.016^{\mathrm{c}}$ & $0.029^{\mathrm{b}}$ & $0.02^{\mathrm{c}}$ & $0.02^{\mathrm{c}}$ & $0.018^{c}$ & 0.003 & $\leq 0.001$ \\
\hline$a+b$ & $0.469^{\mathrm{c}}$ & $0.673^{b}$ & $0.421^{\mathrm{c}}$ & $0.675^{\mathrm{b}}$ & $0.761^{\mathrm{a}}$ & $0.784^{\mathrm{a}}$ & 0.026 & $\leq 0.001$ \\
\hline $\mathrm{ED}^{2}$ & $0.341^{\mathrm{d}}$ & $0.331^{\mathrm{d}}$ & $0.25^{\mathrm{e}}$ & $0.389^{c}$ & $0.436^{\mathrm{b}}$ & $0.466^{\mathrm{a}}$ & 0.006 & $\leq 0.001$ \\
\hline $\mathrm{ED}^{5}$ & $0.262^{\mathrm{c}}$ & $0.215^{\mathrm{d}}$ & $0.177^{\mathrm{e}}$ & $0.269^{c}$ & $0.299^{b}$ & $0.339^{\mathrm{a}}$ & 0.005 & $\leq 0.001$ \\
\hline $\mathrm{ED}^{8}$ & $0.224^{\mathrm{c}}$ & $0.172^{\mathrm{d}}$ & $0.146^{\mathrm{e}}$ & $0.221^{\mathrm{c}}$ & $0.243^{\mathrm{b}}$ & $0.289^{\mathrm{a}}$ & 0.004 & $\leq 0.001$ \\
\hline \multicolumn{9}{|c|}{ Crude Protein (CP) } \\
\hline$A$ & $0.076^{\mathrm{c}}$ & $0.176^{\mathrm{b}}$ & $0.069^{\mathrm{c}}$ & $0.369^{\mathrm{a}}$ & $0.387^{\mathrm{a}}$ & $0.381^{\mathrm{a}}$ & 0.006 & $\leq 0.001$ \\
\hline$B$ & $0.403^{\mathrm{ab}}$ & $0.371^{\mathrm{bc}}$ & $0.365^{\mathrm{d}}$ & $0.302^{\mathrm{d}}$ & $0.434^{\mathrm{a}}$ & $0.384^{\mathrm{bc}}$ & 0.012 & $\leq 0.001$ \\
\hline C & $0.02^{\mathrm{e}}$ & $0.102^{\mathrm{a}}$ & $0.056^{\mathrm{b}}$ & $0.035^{\mathrm{c}}$ & $0.036^{\mathrm{c}}$ & $0.058^{\mathrm{b}}$ & 0.01 & $\leq 0.001$ \\
\hline$a+b$ & $0.478^{\mathrm{e}}$ & $0.547^{\mathrm{d}}$ & $0.434^{\mathrm{f}}$ & $0.671^{\mathrm{c}}$ & $0.821^{\mathrm{a}}$ & $0.765^{\mathrm{b}}$ & 0.013 & $\leq 0.001$ \\
\hline $\mathrm{ED}^{2}$ & $0.297^{\mathrm{d}}$ & $0.449^{\mathrm{b}}$ & $0.315^{\mathrm{d}}$ & $0.401^{b}$ & $0.538^{\mathrm{a}}$ & $0.547^{\mathrm{a}}$ & 0.006 & $\leq 0.001$ \\
\hline $\mathrm{ED}^{5}$ & $0.214^{\mathrm{e}}$ & $0.383^{\mathrm{b}}$ & $0.243^{\mathrm{d}}$ & $0.31^{\mathrm{c}}$ & $0.406^{\mathrm{b}}$ & $0.44^{\mathrm{a}}$ & 0.005 & $\leq 0.001$ \\
\hline $\mathrm{ED}^{8}$ & $0.181^{\mathrm{d}}$ & $0.339^{\mathrm{b}}$ & $0.204^{\mathrm{d}}$ & $0.267^{\mathrm{c}}$ & $0.343^{\mathrm{b}}$ & $0.38^{\mathrm{a}}$ & 0.004 & $\leq 0.001$ \\
\hline \multicolumn{9}{|c|}{ Acid Detergent Fiber (ADF) } \\
\hline$A$ & $0.081^{\mathrm{d}}$ & $0.117^{\mathrm{c}}$ & $0.077^{\mathrm{d}}$ & $0.163^{\mathrm{b}}$ & $0.17^{\mathrm{ab}}$ & $0.178^{\mathrm{a}}$ & 0.003 & $\leq 0.001$ \\
\hline$B$ & $0.29^{\mathrm{d}}$ & $0.435^{\mathrm{b}}$ & $0.293^{\mathrm{d}}$ & $0.437^{\mathrm{b}}$ & $0.496^{\mathrm{a}}$ & $0.385^{\mathrm{c}}$ & 0.012 & $\leq 0.001$ \\
\hline$C$ & $0.077^{\mathrm{a}}$ & $0.031^{\mathrm{cd}}$ & $0.038^{\mathrm{cb}}$ & $0.025^{\mathrm{d}}$ & $0.046^{\mathrm{b}}$ & $0.04^{\mathrm{b}}$ & 00.00 & $\leq 0.001$ \\
\hline$a+b$ & $0.371^{\mathrm{d}}$ & $0.553^{\mathrm{c}}$ & $0.371^{\mathrm{d}}$ & $0.6^{\mathrm{b}}$ & $0.665^{\mathrm{a}}$ & $0.563^{\mathrm{c}}$ & 0.012 & $\leq 0.001$ \\
\hline $\mathrm{ED}^{2}$ & $0.309^{\mathrm{e}}$ & $0.382^{\mathrm{d}}$ & $0.259^{\mathrm{f}}$ & $0.405^{\mathrm{c}}$ & $0.515^{\mathrm{a}}$ & $0.433^{\mathrm{b}}$ & 0.005 & $\leq 0.001$ \\
\hline $\mathrm{ED}^{5}$ & $0.255^{\mathrm{e}}$ & $0.284^{\mathrm{d}}$ & $0.196^{\mathrm{f}}$ & $0.308^{c}$ & $0.407^{\mathrm{a}}$ & $0.348^{\mathrm{b}}$ & 0.003 & $\leq 0.001$ \\
\hline $\mathrm{ED}^{8}$ & $0.221^{\mathrm{e}}$ & $0.239^{\mathrm{d}}$ & $0.165^{\mathrm{f}}$ & $0.267^{\mathrm{c}}$ & $0.351^{\mathrm{a}}$ & $0.305^{\mathrm{b}}$ & 0.003 & $\leq 0.001$ \\
\hline \multicolumn{9}{|c|}{ Neutral Detergent Fiber (NDF) } \\
\hline$A$ & $0.089^{\mathrm{d}}$ & $0.077^{\mathrm{e}}$ & $0.041^{\mathrm{f}}$ & $0.126^{\mathrm{c}}$ & $0.137^{\mathrm{b}}$ & $0.168^{\mathrm{a}}$ & 0.003 & $\leq 0.001$ \\
\hline$B$ & $0.325^{\mathrm{cd}}$ & $0.31^{\mathrm{d}}$ & $0.236^{\mathrm{e}}$ & $0.36^{\mathrm{c}}$ & $0.444^{b}$ & $0.596^{\mathrm{a}}$ & 0.013 & $\leq 0.001$ \\
\hline C & $0.014^{\mathrm{c}}$ & $0.052^{\mathrm{a}}$ & $0.05^{\mathrm{a}}$ & $0.047^{\mathrm{a}}$ & $0.03^{b}$ & $0.014^{\mathrm{c}}$ & 0.00 & $\leq 0.001$ \\
\hline$a+b$ & $0.414^{\mathrm{d}}$ & $0.387^{\mathrm{d}}$ & $0.276^{\mathrm{e}}$ & $0.486^{\mathrm{c}}$ & $0.581^{\mathrm{b}}$ & $0.664^{\mathrm{a}}$ & 0.015 & $\leq 0.001$ \\
\hline $\mathrm{ED}^{2}$ & $0.214^{\mathrm{d}}$ & $0.299^{\mathrm{c}}$ & $0.208^{\mathrm{d}}$ & $0.378^{b}$ & $0.406^{\mathrm{a}}$ & $0.408^{a}$ & 0.006 & $\leq 0.001$ \\
\hline $\mathrm{ED}^{5}$ & $0.156^{\mathrm{c}}$ & $0.234^{\mathrm{b}}$ & $0.158^{\mathrm{c}}$ & $0.3^{\mathrm{a}}$ & $0.306^{\mathrm{a}}$ & $0.295^{\mathrm{a}}$ & 0.004 & $\leq 0.001$ \\
\hline $\mathrm{ED}^{8}$ & $0.134^{\mathrm{c}}$ & $0.198^{\mathrm{b}}$ & $0.131^{\mathrm{c}}$ & $0.259^{\mathrm{a}}$ & $0.26^{\mathrm{a}}$ & $0.259^{\mathrm{a}}$ & 0.004 & $\leq 0.001$ \\
\hline
\end{tabular}

Means sharing same row with different superscripts (a-f) are significantly different $(\mathrm{P} \leq 0.05)$.

${ }^{1}$ In items: a, the quickly disappeared fractions after washing bags with running water; $\mathrm{b}$, slowly degraded fractions; c, degradation rate of $b$ per hour.

$\mathrm{ED}^{2}, \mathrm{ED}^{5}$ and $\mathrm{ED}^{8}=$ Effective degradability, calculated by taking three different passage rates $(0.02 / \mathrm{h}, 0.05 / \mathrm{h}$ and $0.08 / \mathrm{h})$ respectively.

${ }^{2} \mathrm{SEM}=$ Standard error of mean. 
Conclusions: Waste material silage effluent is rich in nutrient and can be used as an inoculant, not only to improve fermentation quality of wheat straw but also to increase its degradation in rumen. Further experiments are required to clarify whether the addition of silage effluent can preserve the ensilage from undesired pathogen i.e. yeast, coliform, clostridia and fungal growth or not.

Acknowledgments: The authors are thankful to East Anatolian Agricultural Research Institute, Erzurum, Turkey for coordinating field activities. The article was extracted from the master thesis prepared by H.G. Qutab ud din under the guidance of Prof. Dr. Muhlis Macit.

\section{REFERENCES}

Ak, İ. and K.C. Akbay (2018). Feed value of wheat hay and use of animal feeding. TÜRKTOB Derg. 25: 20-22. (In Turkish)

Alli, I., C. Thiffault, and B.E. Baker (1985). A device for monitoring silage effluent produced in laboratory silos. J. Dairy Sci. 68: 3355-3359.

A.O.A.C. (1990). Official Methods of Analysis (16th ed). Association of Official Analytical Chemists. Washington, DC. 66- $88 \mathrm{p}$.

Borhami, B.E.A., F. Sundstøl, and T.H. Garmo (1982). Studies on ammonia-treated straw. II. fixation of ammonia in treated straw by spraying with acids. Anim. Feed Sci. Technol. 7: 53-59.

Brown, W.F., J.D. Phillips, and D.B. Jones (1987). Ammoniation or cane molasses supplementation of low quality forages. J. Anim. Sci. 64: 12051214.

Chandra, R., H. Takeuchi, T. Hasegawa, and R. Kumar (2012). Improving biodegradability and biogas production of wheat straw substrates using sodium hydroxide and hydrothermal pretreatments. Energy. 43: 273-282.

Chaturvedi, V. and P. Verma (2013). An overview of key pretreatment processes employed for bioconversion of lignocellulosic biomass into biofuels and value added products. Biotech. 3(5): 415-431.

Dai, J., B. Bean, B. Brown, W. Bruening, J. Edwards, M. Flowers, and J. Ransom (2016). Harvest index and straw yield of five classes of wheat. Biomass and Bioenergy. 85: 223-227.

Dass, R.S., U.R. Mehra, and A.K. Verma (2000). Nitrogen fixation and in situ dry matter and fibre constituent disappearance of wheat straw treated with urea and boric acid in Murrah buffaloes. Asian-Australasian J. Anim. Sci. 13: 11331136.

Duncan, D.B. (1955). Multiple range and multiple F-Test. Biometrics. 11: 1-42 p.
Elobied, G. H., M. T. Yousif, and I. A. Abdalla (2013). Effect of addition of effective microorganisms on chemical and rumen fermentation characteristics of wheat straw treated with four levels of urea. Gezira J. Agr. Sci. 11 p.

Filya, İ. (2000). The effects of some silage additives on the performance of ruminants. Animal Production.41 p.(in Turkish)

Gebrehanna, M. M., R. J. Gordon, A. Madani, A.C. VanderZaag, and J.D. Wood (2014). Silage effluent management: a review. J. of environmental management. 143: 113-122.

Gupta, M.L. and K. Pradhan (1977). Chemical and biological evaluation of ensiled wheat straw. J. Dairy Sci. 60: 1088-1094.

Holmes, B.J. and R.E. Muck (2007). Packing bunkers and piles to maximize forage preservation. Proc. 6th Int. Dairy Housing Conf. ASABE and Harvest and Storage. Accessed Jan. 15, 2017.

Jalilvand, G., A. Naserian, E. Kebreab, N.E. Odongo, R. Valizadeh, F. Eftekhar Shahroodi, S. Lopez, and J. France (2008). Rumen degradation kinetics of alfalfa hay, maize silage and wheat straw treated with fibrolytic enzymes. Arch. Zootec. 57: 155164.

Johnson, L.M., J.H. Harrison, D. Davidson, W.C. Mahanna, K. Shinners, and D. Linder (2002). Corn silage management: effects of maturity, inoculation, and mechanical processing on pack density and aerobic stability. J. Dairy Sci. 85: 434-444.

Kılıç, A. (1986). Silo bait; teaching, learning and implementation recommendations. Bilgehan Publishing House. Bornova-Izmir, 3-327 p. (in Turkish)

Li, Y., U. Merrettig Bruns, S. Strauch, S. Kabasci, and H. Chen (2013z015). Optimization of ammonia pretreatment of wheat straw for biogas production. J. of Chemical Technol. \& Biotechnol. 90(1): 130-138.

Liu. M. and L. Hui (2014). Acetic acid catalyzed steam explosion for improving the sugar recovery of wheat straw. BioRes. 9(3): 4703-4709.

Mahr-un-Nisa, M. Sarwar and M. A. Khan (2004). Influence of ad-libitum feeding of urea-treated wheat straw with or without corn steep liquor on intake, in situ digestion kinetics, nitrogen metabolism, and nutrient digestion in Nili-Ravi buffalo bulls. Australian J. Agric. Res. 55: 229236.

McDonald, I. (1981). A revised model for the estimation of protein degradability in the rumen. J. Agric. Sci. 96 (1): 251-252.

Merali, Z., J.D. Ho, S.R. Collins, G. Le Gall, A. Elliston, A. Käsper, and K.W. Waldron (2013). Characterization of cell wall components of 
wheat straw following hydrothermal pretreatment and fractionation. Biores. Technol. 131: 226-234.

Ni, K., Y. Wang, H. Pang, and Y. Cai (2014). Effect of Cellulase and Lactic Acid Bacteria on Fermentation Quality and Chemical Composition of Wheat Straw Silage. American J. Plant Sci. 05: 1877.

NRC. (2001). 'Nutrient Requirements of Dairy Cattle.' 7th revised edn. National Academy Press: Washington, DC.

Oladosu, Y., M.Y. Rafii, N. Abdullah, U. Magaji, G. Hussin, A. Ramli, and G. Miah (2016). Fermentation quality and additives: A case of rice straw silage. BioMed research international.

Ørskov, E.R. and I. McDonald (1979). The estimation of protein degradability in the rumen from incubation measurements weighted according to rate of passage. J. Agric. Sci. 92: 499.

Palangi, V. and M. Macit (2019). In situ crude protein and dry matter ruminal degradability of heattreated barley. Revue Méd. Vét. 170: 123-128.

Patterson, D.C. and N. Walker (1979). The Use of effluent from grass silage in the diet of finishing pig's variation in composition of effluents. Anim. Feed Sci. Technol. 4: 263-274.

Randby, A.T. (1997). Feeding of silage effluent to dairy cows. Acta. Agric. Scandinavica. 47: 20-30.

SAS. (2004). 'SAS user's guide. Statistics. Statistical Analysis System Inst. Inc.. Carry, NC.

Seale, D. R., H. B. Chr, G. Pahlow, S.F. Spoelstra, S. Lindgren, F. Dellaglio, and J.F. Lowe (1990). Methods for the microbiological analysis of silage. Grovfoder. Presented at the EUROBAC Conference, Uppsala, Sweden, 12-16 Aug. 1986, Sveriges Lantbruksuniv.

Seale, D.R., A.R. Henderson, K.O. Pettersson, and J.F. Lowe (1986). The effect of addition of sugar and inoculation with two commercial inoculants on the fermentation of lucerne silage in laboratory silos. Grass Forage Sci. 41: 61-70.

Van Kuijk, S.J.A., A.S.M. Sonnenberg, J.J.P. Baars, W.H. Hendriks, and J.W. Cone (2015). Fungal treated lignocellulosic biomass as ruminant feed ingredient: a review. Biotechnology advances. 33(1): 191-202.

Van Soest, P.J., J.B. Robertson, and B.A. Lewis (1991). Methods for dietary fiber, neutral detergent fiber, and nonstarch polysaccharides in relation to animal nutrition. J. Dairy Sci. 74: 3583-3597.

Yang, H.Y., X.F. Wang, J.B. Liu, L.J. Gao, M. Ishii, Y. Igarashi, and Z.J. Cui (2006). Effects of watersoluble carbohydrate content on silage fermentation of wheat straw. J. Bios. Bioengin. 101: 232-237.

Yildiz, C., B. Sayinci, and İ. Öztürk (2016). The bioherbic effect of corn silage water "amaranthus retroflexus 1 . and chenopodium album 1." are investigating the availability of the fight against weeds. Ataturk Univ. Ziraat Fak. Derg.45: 99-105.(in Turkish)

Yitbarek, M.B. and B. Tamir (2014). Silage additives. Open J. of Applied Sci. 4(5): 258.

Zhang, M., H. Lv, Z. Tan, Y. Li, Y. Wang, H. Pang, Z. $\mathrm{Li}, \mathrm{Z}$. Jiao, and Q. Jin (2017). Improving the fermentation quality of wheat straw silage stored at low temperature by psychrotrophic lactic acid bacteria. J. Anim. Sci. 88: 277-285.

Zielińska, K., A. Fabiszewska, and I. Stefańska (2015). Different aspects of Lactobacillus inoculants on the improvement of quality and safety of alfalfa silage. Chilean J. Agri. Res. 75(3): 298-306.

Zorrilla-Rios, J., F.N. Owens, G.W. Horn, and R.W. McNew (1985). Effect of Ammoniation of wheat straw on performance and digestion kinetics in cattle. J. Anim. Sci. 60: 814-821. 